\title{
TRANSITIONAL JUSTICE IN SOUTH AFRICA AND BRAZIL: INTRODUCING A GENDERED APPROACH TO RECONCILIATION
}

\author{
GALINA NELAEVA, \\ Tyumen State University (Tyumen, Russia) \\ NATALIA SIDOROVA, \\ Tyumen State University (Tyumen, Russia)
}

DOI: $10.21684 / 2412-2343-2019-6-2-82-107$

The concept of transitional justice has been associated with the periods of political change when a country emerges from a war or turmoil and attempts to address the wrongdoings of the past. Among various instruments of transitional justice, truth commissions stand out as an example of a non-judicial form of addressing the crimes of the past. While their setup and operation can be criticized on different grounds, including excessive politization of hearings and the virtual impossibility of meaningfully assessing their impact, it has been widely acknowledged in the literature that the Truth and Reconciliation Commission in South Africa can be regarded as a success story due to its relatively strong mandate and widespread coverage and resonance it had in South African society. We would like to compare this commission from the 1990s with a more recent example, the Brazilian National Truth Commission, so as to be able to address the question of incorporation of gendered aspects in transitional justice (including examination of sexual violence cases, representation of women in truth-telling bodies, etc.), since gender often remains an overlooked and silenced aspect in such initiatives. Gendered narratives of transitional justice often do not fit into the wider narratives of post-war reconciliation. A more general question addressed in this research is whether the lack of formal procedure in truth commissions facilitates or hinders examination of sexual crimes in transitional settings.

Keywords: transitional justice; truth commissions; post-conflict resolution; gender-based violence; reconciliation. 
Recommended citation: Galina Nelaeva \& Natalia Sidorova, Transitional Justice in South Africa and Brazil: Introducing a Gendered Approach to Reconciliation, 6(2) BRICS Law Journal 82-107 (2019).

\section{Table of Contents}

\section{Introduction: Origins and Historical Context of Transitional Justice 1. Gender-Based Crimes in Transitional Justice: Beyond the Prosecutions? \\ 2. Truth Commissions in South Africa and Brazil \\ 2.1. South African Truth and Reconciliation Commission (TRC) \\ 2.2. Brazilian National Truth Commission (NTC) Conclusion}

\section{Introduction: \\ Origins and Historical Context of Transitional Justice}

Although the term "transitional justice" is relatively recent, and is mostly connected in the literature with post-WWII developments, some authors contend that we can trace the evolution of certain policies regarding post-war reconciliation already in ancient times.' It has to be noted from the very start that in international humanitarian law there is no checklist of transitional measures that must be taken in post-conflict situations (with the exception of criminal prosecution). Thus, transitional justice can been understood very broadly to encompass a whole variety of different instruments and mechanisms applied in different settings in an ad hoc manner. Norwegian scholars Elin Skaar and Camila Gianella Malca define transitional justice as

processes and mechanisms for dealing with past atrocities, covering a range of formal as well as informal mechanisms developed in post-authoritarian and post-conflict situations, including prosecution through courts, truthtelling through truth commissions, victims' reparations, amnesties, vetting, lustration, institutional reform, and memorial process. ${ }^{2}$

Thus, the choice of concrete mechanisms very much depends on the context: whether the country is transitioning from an authoritarian regime to democracy

Anja Seibert-Fohr, Transitional Justice in Post-Conflict Situations, Max Planck Encyclopedia of Public International Law (2015) (Apr. 20, 2019), available at https://opil.ouplaw.com/abstract/10.1093/ law:epil/9780199231690/law-9780199231690-e419?rskey=7mBQue\&result=4\&prd=EPIL.

2 Elin Skaar \& Camila Gianella Malca, Transitional Justice Alternatives: Claims and Counterclaims in After Violence: Transitional Justice, Peace and Democracy 1, 1-28 (E. Skaar et al. (eds.), London and New York: Routledge, 2015). 
or whether it is trying to heal the traumas inflicted by an armed conflict. There are no one-size-fits-all formulas as to which mechanisms would be appropriate and transplantable in any given situation, thus the decision to employ particular measures are context-based and depend on a multitude of factors including institutional capacity, availability of funding, cadres and, perhaps most importantly, political will. The range of transitional justice initiatives is broad and encompasses both judicial and non-judicial mechanisms that include truth-telling, secret files disclosure, prosecution of perpetrators, various mechanisms of redress, institutional reforms, public apology, property restitution, memorialization, and so on. These initiatives increasingly began to be applied by the international community in the 1990s. Since then a whole research agenda has emerged that has looked into various aspects of transitional justice initiatives in an effort to assess their effectiveness, appropriateness and potential for bringing peace and reconciliation.

Astrid Bothmann offers a chronology of transitional justice developments. The first phase began in the aftermath of the atrocities of WWII, when European countries faced the necessity to punish the Nazis, their accomplices and collaborators. ${ }^{3}$ Apart from the Nuremberg trials, several important domestic processes took place in Western Europe, where Nazi criminals, who had been on the run for a long time, were finally captured and brought to justice. In the Western European context, very important post-WWII trials were those held in Germany, and Devin Pendas remarks that they were not only numerous, but also had to address a very complex dilemma: the lack of judges who would not have any connection to the politics of the Third Reich. ${ }^{4}$ In Italy, Belgium and the Netherlands criminal trials were accompanied by a widespread program of lustration, where collaborators were excluded from holding key positions in society. Transitional justice also became subject to widespread public discussion, mostly in the context of memory politics in both European and non-European contexts. ${ }^{6}$

The second phase began with the third wave of democratization (in Huntington's terms) when the concept of retributive justice was gradually abandoned in favor of restorative justice.' This phase was characterized by the widespread establishment of truth commissions in Latin American countries, the most famous of which include CONADEP (Argentinian National Commission on the Disappearance of Persons) set

3 Astrid Bothmann, Transitional Justice in Nicaragua 1990-2012: Drawing a Line Under the Past 27 (Wiesbaden: Springer VS, 2015).

4 Devin O. Pendas, Retroactive Law and Proactive Justice: Debating Crimes Against Humanity in Germany, 1945-1950, 43(3) Central European History 428 (2010).

5 Luc Huyse, Justice After Transition: On the Choices Successor Elites Make in Dealing with the Past, 20(1) Law \& Social Inquiry 51 (1995).

6 Sanya Romeike, Transitional Justice in Germany After 1945 and After 1990, Occasional Paper No. 1, International Nuremberg Principles Academy (2016) (Apr. 20, 2019), available at https://www. nurembergacademy.org/fileadmin/media/pdf/news/Transitional_Justice_in_Germany.pdf.

Bothmann 2015, at 29. 
up in 1983 and Chilean Investigative Commission on the Situation of Disappeared People and its Causes set up in 1990. In Europe, regime change and the transition of Southern European countries to democracy brought about a number of postauthoritarian transition initiatives. ${ }^{8}$

The recent, third phase began in the mid-1990s and includes not only trials and truth commissions, but also a whole variety of other initiatives. The actual term "transitional justice" also emerged during this time, when the first studies of this phenomenon were appeared, for example the report "Transitional Justice: How Emerging Democracies Reckon with Former Regimes," published in 1995 in the United States. Transitional justice is no longer understood as a range of measures applicable in the context of regime change, but rather as a broad approach to deal with post-conflict situations, including civil wars, political turmoil and even natural disasters. According to the United Nations' understanding of transitional justice, it includes such pillars as prosecution initiatives, truth-telling processes, reparation programs and institutional reform, as well as national consultation. ${ }^{9}$

The end of the Cold War brought about new interpretations of peace-keeping, peace-building and post-conflict reconstruction. With the establishment of the U.N. ad hoc tribunals for the former Yugoslavia (ICTY) and Rwanda (ICTR), a whole new debate started on the assumed link between transitional justice and the rule of law. ${ }^{10}$ As Elizabeth Andersen noted,

To summarize, a critical dimension of a rule of law approach to transitional justice is that the transitional justice process is localized, physically situated as close to the rite where the crimes took place as possible, ideally implemented through national and local institutions, and with input to the design and remedy from the affected population."

The connection between transitional justice and democratization also became the topic of lively discussions. ${ }^{12}$

8 António Costa Pinto, Authoritarian Legacies, Transitional Justice and State Crisis in Portugal's Democratization, 13(2) Democratization 173 (2006).

9 United Nations, Guidance Note of the Secretary-General: United Nations Approach to Transitional Justice, DPA/UNSG 2010-00904 (March 2010) (Apr. 20, 2019), available at https://www.un.org/ruleoflaw/ files/TJ_Guidance_Note_March_2010FINAL.pdf.

10 United Nations Security Council, The Rule of Law and Transitional Justice in Conflict and Post-Conflict Societies: Report of the Secretary-General, S/2004/616 (August 2004) (Apr. 20, 2019), available at https://digitallibrary.un.org/record/527647.

11 Elizabeth Andersen, Transitional Justice and the Rule of Law: Lessons from the Field, 47(1) Case Western Reserve Journal of International Law 305 (2015).

12 Siri Gloppen, Reconciliation and Democratisation: Outlining the Research Field, Report R 2002: 5, Chr. Michelsen Institute (2002) (Apr. 20, 2019), available at https://www.researchgate.net/ publication/37166544_Reconciliation_and_Democratisation_Outlining_the_Research_Field. 
At approximately the same time the discussion over universal jurisdiction and the aut dedere aut judicare principle led to several domestic trials in European countries. ${ }^{3}$ In addition, after the collapse of the communist bloc in Central and Eastern Europe, certain measures were taken to ensure the transition to democratic societies. Such measures included, inter alia, open access to secret police files, public denunciation of the crimes committed by the regime and lustration. The implementation of all these measures, however, had very different effects in central and eastern European countries and was accompanied by innumerable political scandals. ${ }^{14}$ Political elites tried to manipulate transitional justice initiatives to discredit their opponents, which made these initiatives increasingly unpopular with the population and instead of fostering reconciliation, polarized society even further. ${ }^{15}$ European dilemmas in the field of transitional justice only demonstrate that there is no blueprint that can be easily transplanted to a traumatized society and ensure miraculous healing. To forget the past or to talk about it: Which is more harmful? All of these issues still bring about serious discussions in many countries. ${ }^{16}$

One of the frequently discussed topics in academic debates over transitional justice is the appropriateness of criminal trials over more flexible truth-telling mechanisms, ${ }^{17}$ as well as the interrelation between the two. ${ }^{18}$ The relation between trials and truth commissions is a complex one. On the one hand, truth commissions do not have legal powers and are not entitled to impose punishment on a perpetrator. On the other hand, they have been praised exactly for this flexibility which criminal trials do not have because they focus on specific aspects of specific conduct, thus, an overall picture of abuses might be missing. ${ }^{19}$ However, as Priscilla Hayner notes in her book, often evidence gathered by the truth commissions might become useful once criminal trials begin. She gives the example of Argentina where information gathered by the truth commission was used in criminal trials.

13 Alicia Gil Gil, The Flaws of the Scilingo Judgment, 3(5) Journal of International Criminal Justice 1082 (2005).

14 Cynthia Horne, Building Trust and Democracy: Transitional Justice in Post-Communist Countries (Oxford: Oxford University Press, 2017).

15 Csilla Kiss, The Misuses of Manipulation: The Failure of Transitional Justice in Post-Communist Hungary, 58(6) Europe-Asia Studies 925 (2006).

16 Controversial Monument Divides Hungarians, Angers Jewish Community, EURACTIV, 23 July 2014 (Apr. 20, 2019), available at https://www.euractiv.com/section/central-europe/news/controversialmonument-divides-hungarians-angers-jewish-community.

17 Donald W. Shriver, Jr., Truth Commissions and Judicial Trials: Complementary or Antagonistic Servants of Public Justice?, 16(1) Journal of Law and Religion 1 (2001).

18 Elizabeth M. Evenson, Truth and Justice in Sierra Leone: Coordination Between Commission and Court, 104(3) Columbia Law Review 730 (2004).

19 Giada Girelli, Understanding Transitional Justice: A Struggle for Peace, Reconciliation, and Rebuilding 201 (Cham: Springer, 2017). 
In just over five months, the prosecution reviewed the commission's nearly 9,000 case files to choose over 800 witnesses to be presented in the trial, covering some 700 individual cases. The trial began just eighteen months after the military junta left power, when the momentum for accountability and public interest was still strong. The trial was a devastating show of calculated horror, allowing the public to hear firsthand accounts of suffering from those who were caught in the web of the military torture centers and managed to survive. ${ }^{20}$

Then, the commission's flexibility also allows for their easier adjustment to specific contexts, and given that they have fewer formal legal and procedural constraints, they are more understandable to the public (which is very often not trained in the specifics of criminal law and criminal procedure).

International organizations, donor agencies, governmental experts, (I)NGOs and local civil society, victims' groups, religious organizations and prominent individuals are the most common actors in transitional justice initiatives. ${ }^{21}$

As far as transitional justice measures are concerned, scholars usually divide them into two broad categories: judicial (which includes trials, both international and domestic) and non-judicial (which encompasses various other initiatives, such as reparation programs, institutional reforms and truth-telling mechanisms, and visualization, including memorials, museums and popular culture).

In the African and Latin American context, the most famous examples of transitional justice are truth commissions/truth and reconciliation commissions. Truth commissions are usually set up by the government as temporary bodies to investigate gross human rights violations committed by the previous regime. The first truth commission was established in Uganda in the 1970s and, according to Amnesty International, in the period of 1974-2007 there were at least thirty-two commissions, working mostly on the African and Southern American continents. ${ }^{22}$ It can be difficult to distinguish truth commissions from other fact-finding bodies. According to Priscilla Hayner, a truth commission:

20 Priscilla B. Hayner, Unspeakable Truths: Confronting State Terror and Atrocity 94 (New York and London: Routledge, 2001).

21 International organizations often act as donors as well. For instance, the European Union has consistently supported transitional justice initiatives and victims' rehabilitation mechanisms. For example, it allocated $€ 5$ million to the development of transitional justice projects in Columbia, $€ 300,000$ for the creation of a Truth Commission on the Solomon Islands and $€ 100,000$ for a project on forced disappearances in Guatemala. For more, see Laura Davis, The European Union and Transitional Justice, IFP Democratisation and Transitional Justice Cluster (June 2010), at 14 (Apr. 20, 2019), available at https://ictj.org/sites/default/files/ICTJ-IFP-EU-Justice-2010-English.pdf.

22 Комиссии по установлению истины // Amnesty International [Truth Commissions, Amnesty International] (Apr. 20, 2019), available at https://amnesty.org.ru/node/609. 
(1) is focused on the past, rather than ongoing, events; (2) investigates a pattern of events that took place over a period of time; (3) engages directly and broadly with the affected population, gathering information on their experience; (4) is a temporary body, with the aim of concluding with a final report; and (5) is officially authorized or empowered by the state under review. ${ }^{23}$

Elin Skaar notes that the main objective of truth commissions is uncovering, recording and documenting the truth, but this list can be easily expanded. She quotes Tristan Anne Borer who made an alphabetical list of truth commissions' objectives that include

accountability, acknowledgment, amnesty, apology, coexistence, confession, dignity, forgiveness, healing, human rights culture, justice, mental health, mercy, national unity, nunca más or "never again," peace, political impact, nonprosecutorial punishment, reconciliation, reconstruction, remorse, reparations, repentance, responsibility, restoration, retribution, rule of law, and, finally, truth. ${ }^{24}$

Skaar remarks, however, that despite their varying mandates their end goal is usually the same: reconciliation. At the end of their activities, they produce a final report that includes their main findings, statistical information and policy recommendations.

The South African Truth and Reconciliation Commission is often cited as an example of the most successful commission that not only explored the crimes of the apartheid regime, but also had certain quasi-judicial powers, which included the granting of amnesty. The Commission was regarded as a model for further similar undertakings and was widely covered in the media, mass culture ${ }^{25}$ and the academic literature. ${ }^{26}$ The Brazilian National Truth Commission, on the contrary, is a relatively recent case, which to date remains unexplored.

In this article, we would like to examine the gender dimension in both commissions with a view to identifying the challenges and achievements of both commissions in the course of "engendering" transitional justice.

23 Priscilla B. Hayner, Unspeakable Truths: Transitional Justice and the Challenge of Truth Commissions 11-12 ( $2^{\text {nd }}$ ed., New York and London: Routledge, 2010).

24 Elin Skaar, Transitional Justice for Human Rights: The Legacy and Future of Truth and Reconciliation Commissions in International Human Rights Institutions, Tribunals, and Courts 401 (G. Oberleitner (ed.), Singapore: Springer, 2018).

25 For instance, the film In My Country (Country of My Skull), 2004 (UK, Ireland, South Africa).

26 We would like to refer the reader to the extensive bibliography included in the Transitional Justice Data Base (TJDB) project (Apr. 20, 2019), available at http://www.tjdbproject.com. 


\section{Gender-Based Crimes in Transitional Justice: Beyond the Prosecutions?}

The question of the gender dimension of transitional justice remains a relatively unexplored area. While there are works that assess the role of women in truth-telling, both as members of various initiatives and as victims/witnesses, there are many more broader aspects that deserve more careful analysis. What is the role of women in democratization? To what extent does women's participation in transitional justice increase the likelihood and durability of transition? Can conclusions be drawn as to the applicability of truth-telling mechanisms in cases of sexual crimes against both men and women? The importance of integrating the gender perspective in transitional justice initiatives has long been recognized by the international community. Thus, a World Bank report states that

incorporating gender-sensitive approaches into the work of the TC not only aids in making effective reparations for victims of human rights abuses, but also helps prevent future conflicts. ${ }^{27}$

Nahla Valji remarks that,

early concerns with gender and truth commission were very much focused on increasing the number of women commissioners, encouraging the employment of women statement-makers and providing a safe space for women to tell their stories of sexual violence. ${ }^{28}$

Since then, however, the emphasis has shifted to include more nuanced narratives of women's experiences in war, since the excessive focus on sexual violence risked misrepresenting women as passive victims of war, devoid of context and overall cultural background, as well as marginalizing certain stories that did not fit into the general picture of reconciliation and forgiveness.

Incorporating gender into transitional justice mechanisms poses numerous questions: How appropriate are truth-telling mechanisms to deal with traumas inflicted by sexual violence? How can transitional justice account for other forms of harm, not just physical harm (social, economic, psychological)? How can transitional justice mechanisms accommodate and balance between both male and female survivors' narratives of war? The lack of trained professionals and the lack of resources

27 World Bank, Gender, Justice, and Truth Commissions (June 2006), at ix (Apr. 20, 2019), available at http://siteresources.worldbank.org/INTLAWJUSTINST/Resources/GJTClayoutrevised.pdf.

28 Nahla Valji, Gender Justice and Reconciliation in Building a Future on Peace and Justice: Studies on Transitional Justice, Peace and Development 217, 228 (K. Ambos et al. (eds.), Heidelberg: Springer, 2009). 
to provide psychological and other forms of help to victims can lead to further traumatization and stigma. ${ }^{29}$ To be fair, the same could be said about criminal trials (both international and domestic), which are often not well equipped to deal with the complexity of such horrendous acts and their long-term consequences..$^{30} \mathrm{Among}$ the challenges that international tribunals face in addressing gender-based sexualized violence we must mention procedural hurdles that hamper effective investigation and prosecution of such assaults. In the conditions where a certain passage of time occurred between the occurrence of actual crimes and prosecution, the most common way of collecting evidence would be witness testimony (accompanied by photographic evidence, if any, and/or by the perpetrator's confession). In domestic law, however, the range of evidence normally used to prove sexual crimes is wider, and also includes material evidence (biological samples, items used in the course of the crime, etc.), medical examination, forensic evidence and experts' conclusions, which are impossible to obtain in times of war, when the assaults often continue for a prolonged period of time (in cases of sexual slavery or forced marriage). Thus, the defense is often left with a dearth of evidence, but at the same time, cannot disregard the rights of the defendants since in such a case the idea of transferring democratic values to a post-conflict society would seem meaningless. It does not come as a surprise, then, that the number of cases where rape charges were dropped supersede the number of actual convictions. For instance, in the International Criminal Tribunal for the Former Yugoslavia, 78 individuals were charged with sexual violence (out of 161 accused), but only 32 were eventually convicted. ${ }^{31}$

In a traditional patriarchal society where societal relations are regulated by cultural and religious norms even this minimal range of available evidence might be abandoned in the favor of the perpetrators. If testifying is not accompanied by victim-friendly procedures and victim support measures, additional psychological trauma will be inevitable. Security/dignity/privacy concerns would explain the victims' reluctance to come forward with their stories. Even though Anne-Marie de Brouwer argues that in the international context, namely, in the International Criminal Court, direct victim testimony is not a necessary precondition for prosecution, ${ }^{32}$ nonetheless it is up to the Chamber to decide on the relevance and applicability of other evidence (the testimony of eyewitnesses, accounts provided by expert witnesses, documentary evidence).

29 Karen Brounéus, The Trauma of Truth Telling: Effects of Witnessing in the Rwandan Gacaca Courts on Psychological Health, 54(3) Journal of Conflict Resolution 408 (2010).

30 See, generally, Nicola Henry, War and Rape: Law, Memory and Justice (London: Routledge, 2011).

${ }^{31}$ In Numbers (as of September 2016), ICTY (Apr. 20, 2019), available at http://www.icty.org/en/features/ crimes-sexual-violence/in-numbers.

32 Anne-Marie de Brouwer, Cases of Mass Sexual Violence Can Be Proven Without Direct Victim Testimony in Contemporary Issues Facing the International Criminal Court 282 (R.H. Steinberg (ed.), Leiden: Brill; Nijhoff, 2016). 
Truth commissions, therefore, compared to trials, might be more suitable venues in which to assess the extent of sexual crimes and the general context accompanying them, however. In a criminal trial, the limitations as to the applicability of evidence, time constraints and other limitations might discourage (or outright reject) certain witness testimony, while truth commissions, on the contrary, can accommodate more victims who come forward with their stories (as long as the design of the commission so permits). In addition, truth commissions might be more suitable institutions for accommodating alternative discourses that encompass a multitude of women's experiences in war, not just their identity as victims. Drawing on extensive field research, Wendy Lambourne and Vivianna Rodriguez Carreon demonstrate, for example, how adopting a narrow, legal focus on prosecutions can be inappropriate to address the multitude and complexity of harms experienced by women in war, and how other aspects (socioeconomic, political and psychological) must be tackled in addition to formal, legal justice. ${ }^{33}$ They note, in particular, that in a formal trial lawyers have control over the evidence to be presented, and victims/witnesses might be discouraged to focus on sexual crimes, interrupted or prevented from speaking about their experience altogether, since the prosecution would only need specific factual information to be able to secure a conviction. ${ }^{34}$ Witnesses might also face threats if they choose to testify as well as fear being marginalized and rejected by their community if they choose to speak up. $^{35}$ Lambourne and Rodriguez Carreon warn, however, that short-term transitional measures are simply not enough to address the complexity of the customary, cultural, social, political and other forces that put women at a disadvantage in society (for instance, women might continue to live in extreme poverty, have little access to education and training, become victims of domestic violence, etc.), and they conclude that it is necessary to complement existing judicial and non-judicial mechanisms with other initiatives, for instance, legislative reforms that would alter the discriminatory status of women (for instance, in inheritance or land rights). An important point they raise is that very often violence against women can take many forms. Referring to the study conducted in northern Uganda, they list several dimensions of violence:

sexual or reproductive coercion, harm, torture or mutilation; targeting women's mothering; women, productive labour and property; women and social capital; and gender multipliers of violence. ${ }^{36}$

33 Wendy Lambourne \& Vivianna Rodriguez Carreon, Engendering Transitional Justice: A Transformative Approach to Building Peace and Attaining Human Rights for Women, 17(1) Human Rights Review 71 (2016).

34 Id. at 76.

35 African Rights \& REDRESS, Survivors and Post-Genocide Justice in Rwanda:Their Experiences, Perspectives and Hopes (November 2008) (Apr. 20, 2019), available at https://reliefweb.int/sites/reliefweb. int/files/resources/EACB1B6625BA02A9C1257524003899EF-Full_Report.pdf. 
Thus, no fool-proof recipes are available on how to design a transitional justice program that would address the needs of all victims in all possible settings. In the context of post-conflict traumas, the ways in which gender is understood and (re) interpreted in public settings influence not only the future of state institutions but also the societal structures more generally.

It has been noted in the literature that in cases when appropriate mechanisms are not in place (such as in camera hearings), speaking publicly about sexual crimes might be in itself a traumatizing experience that would discourage victims from coming forward. However, as Valji points outs, the assumption that women do not want to come forward with their stories does not hold true, it very much depends on the context and on the individual woman. ${ }^{37}$ There are many examples of women who wanted to speak of their experience in public, but they did not always have this possibility. ${ }^{38}$

Moreover, excessive focus on women in transitional justice (in both trials and truth-telling mechanisms) as victims of war obscures other forms of women's experiences such as direct participation in combat. Former women combatants might find it impossible to obtain certain services and enter rehabilitation programs. ${ }^{39}$ The problem of female perpetrators has not been adequately addressed in the literature ${ }^{40}$ thus very little is known about how to address the specific needs of female perpetrators so as to enable their reintegration into the society. Women's participation in atrocities, including sexual crimes, is mostly silenced or downplayed in transitional justice. Suzannah Linton, however, notes quite shocking numbers of women who were accused of international crimes and were tried in some way or another: hundreds of women were tried in the aftermath of WWII, 96,000 were processed in Rwanda through gacaca courts, around 30\%-40\% of combatants in the Liberian civil war were women and around $25 \%$ of gang rapes committed in Sierra Leone involved women as perpetrators. ${ }^{41}$

In addition, male victims of sexual violence might also be discouraged from participating in such narrow-tailored initiatives that equate "gender" with "women" due to the predominant view that only women can be victims of such crimes. Elisabeth Porter strongly argues in favor of "gender-aware truth processes," since

37 Valji 2009, at 230.

38 Vasuki Nesiah et al., Truth Commissions and Gender: Principles, Policies, and Procedures, International Center for Transitional Justice (July 2006) (Apr. 20, 2019), available at https://www.ictj.org/sites/default/ files/ICTJ-Global-Commissions-Gender-2006-English_0.pdf.

39 Laura Stovel, Long Road Home: Building Reconciliation and Trust in Post-War Sierra Leone (Antwerp: Intersentia, 2010).

40 Laura Sjoberg, Women as Wartime Rapists: Beyond Sensation and Stereotyping (New York: New York University Press, 2016).

${ }^{41}$ Suzannah Linton, Women Accused of International Crimes: A Trans-Disciplinary Inquiry and Methodology, 27(2) Criminal Law Forum 159 (2016). 
these processes avoid viewing women solely as victims, or men solely as perpetrators of abuse, but consider men's and women's experiences as fighters, survivors, perpetrators, victims, community leaders, or household managers. ${ }^{42}$

Thus, this multitude of identities, including gender, color and social class, must be taken into account in the layout of truth-telling initiatives.

\section{Truth Commissions in South Africa and Brazil}

\subsection{South African Truth and Reconciliation Commission (TRC)}

The South African Truth and Reconciliation Commission (TRC) was set up in the 1990 s as a response to apartheid that plagued the country for almost fifty years. The Commission, established in 1995 by the Promotion of National Unity and Reconciliation Act, worked from 1996 until 1998, though it took a few more years to finalize its amnesty hearings (2001) and publish its final report (2002). The rationae temporis of the Commission covered the period from 1960 until 1994 during which the apartheid regime was in control in the country. The structure of the Commission included three bodies, namely the Human Rights Violations Committee, the Amnesty Committee and the Reparation and Rehabilitation Committee. The 1995 Promotion of National Unity and Reconciliation Act required the Commission to establish

as complete a picture as possible of the causes, nature and extent of the gross violation of human rights which were committed during that period. ${ }^{43}$

The establishment of the Commission was in many ways a political compromise between formal prosecutions and forgetting. The National Party (NP) that had been in power for more than forty years and engaged in brutal excesses in the era of apartheid would have preferred blank amnesty. The African National Congress (ANC), headed by Nelson Mandela, would have opted for Nuremberg-style trials. As a result of long political negotiations, a compromise was reached in 1993, within the framework of the Interim Constitution. At the core of this compromise lay the idea of confessing the truth, for the granting of amnesty, or, otherwise, criminal prosecution (a "carrot and stick" approach). ${ }^{44}$

Not only this political arrangement, but also the underlying concept of the Commission's work, the concept of ubuntu, has not been without controversy. Thus, Hanneke Stuit

42 Elisabeth Porter, Gendered Narratives: Stories and Silences in Transitional Justice, 17(1) Human Rights Review 35 (2016).

43 Promotion of National Unity and Reconciliation Act 34 of 1995 (Apr. 20, 2019), available at http:// www.justice.gov.za/legislation/acts/1995-034.pdf.

44 For more, see Jeremy Sarkin, Carrots and Sticks: The TRC and the South African Amnesty Process (Antwerp: Intersentia, 2005). 
examines, how "the TRC's discourse on nation-building-through-forgiveness relied on and interacted with the concept of ubuntu and... how this interrelation has influenced the meaning of ubuntu, ${ }^{\prime \prime 5}$ to demonstrate that "any consolidation of the notion of ubuntu (or of the human) runs a continuous risk of becoming just another dominant discourse in need of questioning."46 Ubuntu is a traditional South African concept which symbolizes, in very simple terms, that harm inflicted on one human being by another human being harms them both. This understanding of common humanity, which binds all people together, posits forgiveness as an act that is vital to both the victim and the perpetrator, and to the whole community, to enable the community to move beyond the traumatic experience. Since there is no word that would adequately render this traditional term in European languages, researchers often engage in theological, philosophical and linguistic analysis trying to grasp the nuances in its etymology and application (added to this is the difficulty that ubuntu was predominantly an oral cultural tradition and did not exist in any form of written expression). It is not uncommon to see various analyses of Archbishop Desmond Tutu's memoir "No Future Without Forgiveness, ${ }^{147}$ where he clarifies that,

It is not "I think therefore I am."It says rather: "I am human because I belong." I participate, I share. ${ }^{48}$

This concept, though controversial and contested, has become the central theme in the Commission's work.

On amnesty, the South African TRC is remarkable for its mandate to examine amnesty applications and make decisions concerning them. In doing so, it introduced several criteria for granting amnesty. While asking for forgiveness was not one of them, it was important to demonstrate that the act/omission could be qualified as a gross human rights violation; the motive of the perpetrator had to have a political objective; and the applicant had to make a public disclosure of his or her acts. ${ }^{49} \mathrm{All}$ in all, the TRC received around 7,000 applications for amnesty; however, 5,000 were rejected. Around 1,700 were heard through public hearings (out of which 1,300 ended up in full or partial amnesty). Applications were rejected mostly because of the lack of a "political motive."

45 Hanneke Stuit, Ubuntu Strategies: Constructing Spaces of Belonging in Contemporary South African Culture 41 (London: Palgrave, 2016).

46 Id. at 43 .

47 Archbishop Desmond Tutu was the Commission's Chairman.

48 Quoted in Stuit 2016, at 9.

49 Promotion of National Unity and Reconciliation Act, supra note 43, Chapter 2.

50 Truth and Reconciliation Commission of South Africa Report, Vol. 1, Chapter 10, Statistical Information (Apr. 20, 2019), available at http://www.justice.gov.za/trc/report/finalreport/Volume\%201.pdf. 
Another concern is the question of reparations. The TRC had a mandate, through its Reparation and Rehabilitation Committee, to accord a certain amount of money to those individuals who were recognized by the TRC as victims of gross human rights violations (around 18,000 people). Though it is recognized that reparations can be an indispensable component of transitional justice, some caution is necessary as to their potential healing effect. A study conducted in 2004 by South African scholar Oupa Makhalemele found that the effect of this program was controversial, at best. ${ }^{51}$ First of all, the government did not consult local NGOs or survivors' groups when deciding on the sum of money to be paid (which made it impossible to tailor them to the specific needs of the survivors and to build a comprehensive reconstruction policy). Neither was the reparations policy a matter of public debate. She assumes that such an approach might have been the result of the state's priorities at the time of the establishment of the TRC, since amnesties, and not reparations, were on the top of the list. By conducting interviews with the survivors from a rural settlement (ten men and ten women) and with some government officials from the Housing, Health, Welfare and Education Departments, responsible for the provision of policies relating to the survivors, the researcher attempted to assess the survivors' experiences in the aftermath of the truth and reconciliation process.

An important finding was that despite the TRC's initial focus on reconciliation, it could not be achieved overnight, once the victims had told their stories. The effects of trauma (both physical and psychological) are long-lasting, and would not end just because a certain amount of money as compensation was received. Among the needs that survivors listed as important were

acknowledgement of wrong done, revelation of the truth; exhumation of the bodies of victims, pension rights, medical and educational services, social security, housing, and restoration of reputation. ${ }^{52}$

However, even if the survivors were able to meet certain needs (for example, they were able to afford medical treatment), they feared that once the money ran out, they would be left alone with their troubles, without further assistance (in the field of employment and training, for instance, given that often the survivors had certain physical disabilities as a result of the harm they endured, and could not find just any job that ordinary citizens could). Thus, she concludes that the allocated money has "not made any meaningful impact on the survivors' quest to overcome the consequences of their victimisation.".53

51 Oupa Makhalemele, Still Not Talking: Government's Exclusive Reparations Policy and the Impact of the 30000 Financial Reparations on Survivors, Centre for the Study of Violence and Reconciliation (January 2004) (Apr. 20, 2019), available at http://www.csvr.org.za/docs/reconciliation/stillnottalking.pdf.

52 Id. at 12.

$53 \quad$ Id. at 17. 
While reparations remain an important and essential component of transitional justice, this research shows that careful planning and involvement of victims in the reparations negotiations and planning at all stages is necessary to ensure the adjustment of programs to the specific needs of individuals and communities more generally. Reparations cannot be conducted in isolation, they must involve other measures to address the survivors' urgent needs such as medical counselling, health issues, education and training, housing, and so on.

As far as gender-sensitive strategies are concerned, it is recognized that due to the involvement of NGOs and academics in the processes, the public hearings were organized where women could come forward with their stories. In this regard,

the South Africa case set an important precedent in the incorporation of a gender perspective in a TRC. ${ }^{54}$

What were the forms of women's involvement in the Truth Commission? One of the authoritative and frequently quoted studies in this regard is the one conducted by a South African scholar, Pumla Gobodo-Madikizela. Based on extensive field research that included interviews and archival work, this study investigated women's contributions to transitional justice whether as truth commission employees or through their testimonies as victims and witnesses..$^{55}$ Gobodo-Madikizela emphasizes how in the post-apartheid conditions it was vital to include both white women and women of color in the transitional processes (black African women's testimonies comprised around $60 \%$ of the women's statements, and women's statements more generally comprised more than half of all statements). Having women among the Commission's staff was also very important, because it ensured a more compassionate and female-friendly environment (instead of seeing women as a "crying team" of the Commission, as was the common term used by the media). Special hearings were organized for women to speak about their experiences during apartheid. Such special women-only hearings were held in various regions of the country. Women were also given the possibility to testify behind screens. Women who chose to testify were often regarded as "secondary victims," that is they lost their family members (fathers, husbands or sons) as the result of atrocities, but the activists emphasized that this wrongful representation of women was due to the cultural prejudices that downplayed women's experiences:

People would come in and ravage their houses in the middle of the night and take away their husbands. It is a direct experience of victimization and suffering. It is presented as secondary because of the nature of our society

54 Gender, Justice, and Truth Commissions, supra note 27, at ix.

55 Pumla Gobodo-Madikizela, Women's Contributions to South Africa's Truth and Reconciliation Commission, Women Waging Peace (February 2005) (Apr. 20, 2019), available at https://www.inclusivesecurity. org/wp-content/uploads/2012/08/11_women_s_contributions_to_south_africa_s_truth_and_ reconcilliation_commission.pdf. 
and the way women have learned to keep themselves in the backgroundthe kind of fear about focusing on themselves. ${ }^{56}$

Gobodo-Madikizela attributes the relative success of the TRC in the genderrelated aspects to the active involvement of civil society, women's advocacy groups and other women's rights' organizations in the work of the Commission. One notable example is the submission prepared by the activists from the Gender Research Project of the Centre for Applied Legal Studies (CALS) and the Centre for the Study of Violence and Reconciliation. In their submission, they emphasized that

a gendered approach requires looking at the way society locates women and men in relation to all areas of their lives. Thus, women's experience cannot be understood in isolation from men's, but only with reference to the intertwining of women's and men's roles and status in society generally that is, with women subordinate to men. ${ }^{57}$

Regarding sexual crimes, it was found that it was very difficult for women to come forward with stories of sexual violence or even to admit that they were victims of it. It was even more difficult for men, since

sexual torture of men aimed to induce sexual perversity and to abolish political power and potency, whereas behind the sexual torture of women lay the activation of sexuality to induce shame and guilt. ${ }^{58}$

The problem was that many women, who chose to submit a statement to the TRC, never appeared at the hearings. In their examination of sexual violence in the South African context, Beth Goldblatt and Sheila Meintjes mention that by April 1997,

of the nearly 8,000 statements received on rights violations, only 300 deal with sexual assault and of these, only 80 relate to sexual assault on women. Only 17 of 80 deal with rape and these mostly occurred in Kwazulu-Natal... where the conflict followed the more typical contours of open warfare. ${ }^{59}$

Thus, despite rather active participation of women in transition in a variety of different roles that included, to quote Gobodo-Madikizela, "commissioners, activists,

56 Ingrid Owens et al., Stories of Silence: Women, Truth and Reconciliation, 30 Agenda 66, 69 (1996).

57 Gender, Justice, and Truth Commissions, supra note 27, at 12.

58 Id. at 13 .

59 Beth Goldblatt \& Sheila Meintjes, Dealing with the Aftermath: Sexual Violence and the Truth and Reconciliation Commission, 36 Agenda 10 (1997). 
bystanders, beneficiaries, victims, and survivors," ${ }^{110}$ it was not enough to ensure a safe environment for the survivors of sexual violence. Social stigma and long-standing patterns of abuse and discrimination prevented consideration of other forms of gender-based assaults as human rights violations, for instance, body searching of females by male guards or failure to provide women basic sanitary items. In addition, a problem that frequently occurred in other contexts ${ }^{61}$ was prevalent in South Africa as well: sexual assault of women who belong to the same ethnic or political group. ${ }^{62}$

Assessing the impact of truth commissions is not an easy task. In 2004, James Gibson published a study titled "Overcoming Apartheid: Can Truth Reconcile a Divided Nation?," ${ }^{\prime 3}$ where he used questionnaires and conducted face-to-face interviews with ordinary people from South Africa, trying to evaluate their attitudes towards the TRC and its potential for reconciliation. Don Foster notes that Gibson's study in fact demonstrated that the situation was "not nearly as gloomy as is often portrayed," in that,

Along with stark inequalities and the continued salience of racialized identities, there are also glimmerings in these data of commonalities and some degree of optimism.

Thus, "there is, in short, some fertile ground for the seeds of reconciliation." ${ }^{\prime 64} \mathrm{An}$ interesting finding in this research was that it demonstrated how other forms of justice (compensation, apologies, etc.) in a way compensated for the unfairness of amnesty (when amnesty was seen by the majority of the respondents as unfair).

It suggests that compensation, giving voice to victims, apologies, and shaming may all be part of the mix. It suggests that the informal justice of the TRC may have some advantages over the formal justice of costly trials. ${ }^{65}$

Very little was said about gender peculiarities, however.

Quite often it is assumed that public revelations of the harm endured contributes to healing and reconciliation. Some researchers, however, warn against this widespread

60 Gobodo-Madikizela, supra note 55 , at 8.

61 Maureen Murdoch, Prevalence of In-Service and Post-Service Sexual Assault Among Combat and Noncombat Veterans Applying for Department of Veterans Affairs Posttraumatic Stress Disorder Disability Benefits, 169(5) Military Medicine 392 (2004).

62 Goldblatt \& Meintjes 1997, at 12.

63 James L. Gibson, Overcoming Apartheid: Can Truth Reconcile a Divided Nation? (New York and Cape Town: Russell Sage Foundation, 2004).

64 Don Foster, Evaluating the Truth and Reconciliation Commission of South Africa, 19(4) Social Justice Research 527, 531 (2006).

65 Id. at 538. 
assumption, emphasizing that this might be a typically Western understanding of healing, which has its roots in the Western practice of psychotherapy. Transplanted to a different setting, this approach can in fact do more harm than good, since in some societies forgetting might be a more appropriate form of dealing with past traumas. ${ }^{66}$ Coming to terms with the past does not necessarily involve providing testimony as a form of healing. ${ }^{67}$ This is especially true in the case of sexual violence since women might be stigmatized by their community if they choose to acknowledge the wrongs they have lived through, and in the context of extreme poverty, economic inequalities and the lack of resources to improve their life conditions, women might be left without any means to survive. Truth commission very often are simply not equipped to deal with the enormous task of providing support in cases of re-traumatization. ${ }^{68} \mathrm{In}$ the context of South Africa, it was stressed that some women had already developed certain mechanisms of dealing with the trauma, and they did not see themselves as victims, but as survivors. In addition, they did not want to give up their privacy by publicly acknowledging sexual assaults, because they feared it might have negative repercussions for their careers. ${ }^{69}$

\subsection{Brazilian National Truth Commission (NTC)}

The Brazilian National Truth Commission was set up in 2011 to investigate crimes committed during military rule. The Brazilian NTC was in many ways unique in the Latin American context. First of all, it addressed crimes that had been committed almost three decades earlier; additionally, it had relatively fewer victims to deal with (434 officially recognized victims), compared to other countries like Argentina (between 8,000 and 30,000) or Chile (between 3,216 and 9,000). ${ }^{70}$ Despite its rather limited impact, certain positive outcomes have been noted: namely, "improving historical accountability; promoting international human rights norms; and challenging the veto power that the military still holds." ${ }^{171}$ It is not surprising that, similar to the South African Commission, which was widely discussed in the media and in the public domain more generally, the Brazilian truth-telling experience also received country-wide resonance. The Commission's establishment was applauded

66 Rosalind Shaw, Memory Frictions: Localizing the Truth and Reconciliation Commission in Sierra Leone, 1(2) International Journal of Transitional Justice 183 (2007).

67 See also Fiona Ross, Bearing Witness: Women and the Truth and Reconciliation Commission in South Africa (London: Pluto Press, 2003).

68 Shana Tabak, False Dichotomies of Transitional Justice: Gender, Conflict and Combatants in Columbia, 44 New York University Journal of International Law and Politics 103 (2011).

69 Goldblatt \& Meintjes 1997, at 11.

70 Marcelo Torelly, Assessing a Late Truth Commission: Challenges and Achievements of the Brazilian National Truth Commission, 12(2) International Journal of Transitional Justice 194 (2018).

71 Id. at 194. 
by Human Rights Watch and other prominent INGOs that continuously called on Brazil to bring the perpetrators to justice. ${ }^{72}$

The rationae temporis of the Commission extended to the period of military rule, 1964-1985 (although the Commission looked into a much wider time frame). The difficult question of amnesty was not less relevant in the Brazilian context than in the context of South Africa. Amnesty law was passed in 1979 that shielded the perpetrators from justice. ${ }^{73}$ As Rebecca Atencio stresses, this period was characterized by Cold War rivalries (recalling that the Cuban revolution took place a few years before the start of this period) and the struggle against communism. This provided justification for the military hold on to power. This was also the period of economic boom in Brazil due to the large-scale projects sponsored by the state, which enjoyed popular support, and in a way, drew the public's attention away from grave human rights violations. ${ }^{74}$ While the Commission's focus was on crimes committed by the state, it did not look into the activities of the armed left wing groups that opposed the dictatorship, which was seen as a disadvantage. ${ }^{75}$

It must be noted that prior to 2011 two other commissions had already been at work in Brazil: the Special Commission on Political Deaths and Disappearances (established by Law No. 9.410, the Law of the Disappeared, in 1995) during the presidency of Fernando Henrique Cardoso and the Amnesty Commission (2001). Civil society groups and human rights activists participated actively in investigating the fate of their loved ones and produced two famous reports: "Brazil: Never Again" (under the leadership of Archbishop Cardinal Paulo Evaristo Arns), which was later introduced in a digital form as an online platform with extensive information about

72 Brazil: Prosecute Dictatorship-Era Abuses - Landmark International Decision Provides Powerful Push for Accountability, Human Rights Watch, 14 April 2009 (Apr. 20, 2019), available at https://www.hrw. org/news/2009/04/14/brazil-prosecute-dictatorship-era-abuses.

73 Certain provisions of the amnesty law were declared incompatible with the American Convention on Human Rights: "The provisions of the Brazilian Amnesty Law that prevent the investigation and punishment of serious human rights violations are not compatible with the American Convention, lack legal effect, and cannot continue as obstacles for the investigation of the facts of the present case, neither for the identification and punishment of those responsible, nor can they have equal or similar impact regarding other serious violations of human rights enshrined in the American Convention which occurred in Brazil." Gomes Lund et al. ("Guerrilha do Araguaia") v. Brazil, Preliminary Objections, Merits, Reparations, and Costs, Judgment, 24 November 2010, at 113 (Apr. 20, 2019), available at http://corteidh.or.cr/docs/casos/articulos/seriec_219_ing.pdf. Brazil, however, did not abide by the ruling. For more, see Brazil: Panel Details "Dirty War" Atrocities: Truth Commission Identifies Abusers, Calls for Prosecutions, Human Rights Watch, 10 December 2014 (Apr. 20, 2019), available at https:// www.hrw.org/news/2014/12/10/brazil-panel-details-dirty-war-atrocities.

74 Brazilian Truth Commission: Rebecca Atencio's Interview on BBC Live 5, Tulane University (Apr. 20, 2019), available at https://stonecenter.tulane.edu/articles/detail/1739/Brazilian-Truth-CommissionRebecca-Atencios-Interview-on-BBC-Live-5.

75 Dom Phillips, Brazil Confronts Horrors of the Past with Torture Report's Release, Time, 10 December 2014 (Apr. 20, 2019), available at http://time.com/3629031/brazil-torture-report-truth-commission. 
more than 7,000 prisoners, ${ }^{76}$ and "The Report of the Families of Dead and Disappeared Persons." ${ }^{177}$ Reparations schemes, court-ordered or mandated by the state, also existed prior to the NTC. By the mid-2010s, the abovementioned Amnesty Commission had awarded financial compensation in over 12,000 cases. $^{78}$

The NTC consisted of seven commissioners and fourteen other employees. They had the mandate to collect and examine the truth by receiving written statements and testimonies, interviewing relevant individuals, holding public hearings, establishing links with domestic and international organizations, to request information from various organs, and request witness protection. The Commission worked for two years and seven months. The Commission's final report that came out in 2014 identified hundreds of cases of torture, rape, killings and enforced disappearances. ${ }^{79}$ Various forms of torture were documented by the Commission, such as electric shocks to the genitals, psychological abuse, etc. Allegations were made that the United States trained Brazilian military cadres in the use of various interrogation techniques that amounted to torture..$^{80}$ In widely publicized images, one could see the then Brazilian President Dilma Rousseff who broke into tears at a ceremony dedicated to the NTC's report. ${ }^{81}$ Rousseff, who herself was a victim of torture when in her youth she participated in a Marxist movement, reportedly said during the ceremony that,

We hope this report prevents ghosts from a painful and sorrowful past from seeking refuge in the shadows of silence and omission. ${ }^{82}$

76 BRASIL: NUNCA MAIS (Apr. 20, 2019), available at http://bnmdigital.mpf.mp.br/en-us.

77 Comissão de Familiares de Mortos e Desaparecidos Políticos (Apr. 20, 2019), available at http://www. desaparecidospoliticos.org.br/quem_somos_comissao.php?m=2.

78 Comparative Country Studies Regarding Truth, Justice, and Reparations for Gross Human Rights Violations: Brazil, Chile, and Guatemala, IHRLC Working Paper Series No. 2 (April 2014), at 24 (Apr. 20, 2019), available at https://www.law.berkeley.edu/wp-content/uploads/2015/04/Working-Paper-2India-Comparative-Country-Studies-151027.pdf.

79 Conheça e acesse o relatório final da CNV, Comissão Nacional da Verdade, 10 December 2014 (Apr. 20, 2019), available at http://cnv.memoriasreveladas.gov.br/index.php/outros-destaques/574-conhecae-acesse-o-relatorio-final-da-cnv.

80 Hayes Brown, The U.S. Spent Decades Teaching Torture Techniques to Brazil, BuzzFeed News, 10 December 2014 (Apr. 20, 2019), available at https://www.buzzfeednews.com/article/hayesbrown/the-unitedstates-spent-decades-teaching-torture-techniques.

81 Relatório da Comissão Nacional da Verdade apresenta história de 434 presos e desaparecidos políticos, TV NBR, 10 December 2014 (Apr. 20, 2019), available at https://www.youtube.com/ watch?v=a5dEzgvby8w.

82 Simon Romero, Brazil Releases Report on Past Rights Abuses, New York Times, 10 December 2014 (Apr. 20, 2019), available at https://www.nytimes.com/2014/12/11/world/americas/torture-report-on-braziliandictatorship-is-released.html. 
The report's findings were contested by the representatives of the military, who declared they had done all they could to prevent communism from happening. ${ }^{83}$ The Commission identified 377 persons responsible for human rights violations during military rule (about 100 of whom were still alive); however, due to the 1979 amnesty, the Commission had no mandate to initiate prosecutions. Moreover, in 2010 the Supreme Court of Brazil blocked a request to modify the amnesty law despite calls from various human rights organizations. ${ }^{84}$

Various working groups operated within the Commission. Alongside the Commission, local governments and civil society groups created around fifty local commissions by the end of $2012 .{ }^{85}$ One of the working groups was titled "Dictatorship and Gender" and looked into cases of sexual abuse. As far as sexual crimes are concerned, various forms of these horrendous assaults were identified by the Commission. Volume I, Chapter 10 of their report ("Sexual Violence, Gender Violence and Violence Against Women and Children") identifies various forms of sexual violence, which include rapes and gang rapes, rape including insertion of foreign objects, mutilation of sexual organs, torture and beatings of pregnant women to induce abortion. ${ }^{86}$ The victims included not only political activists but also nuns and LGBT people. ${ }^{87}$ According to Brazilian researcher Maria Amélia de Almeida Teles a significant part of the truth was brought to light due to the desire of victims/survivors to speak publicly about their experiences. It was because of their willingness that such crimes as kidnapping, torture, murder, concealment of corpses, as well as gender-based violence, including torture, forced abortion, sterilization, and other forms of sexual atrocities, were uncovered. ${ }^{88}$

It is difficult, if not impossible, to assess the impact of the truth commission on gendered societal structures. Another Brazilian scholar, Mariana Joffily, for example, notes that sexual violence (against both men and women) was a widespread problem in Latin American dictatorships, and continues to be a problem until the present day. Misogynist and sexist attitudes combined with high levels of social and economic inequality create conditions that make it difficult to adequately address this problem in

83 Romero, supra note 82.

84 Adam Taylor, Brazil's Torture Report Brings a President to Tears, Washington Post, 10 December 2014 (Apr. 20, 2019), available at https://www.washingtonpost.com/news/worldviews/wp/2014/12/10/brazilstorture-report-brings-a-president-to-tears/?noredirect=on\&utm_term=.59bc55839d00.

85 Torelly 2018, at 200.

86 Capítulo 10: Violência sexual, violência de gênero e violência contra crianças e adolescents (Apr. 20, 2019), available at http://cnv.memoriasreveladas.gov.br/images/documentos/Capitulo10/ Capitulo\%2010.pdf.

87 For a detailed account of human rights assaults committed against women, see Maria Amélia de Almeida Teles, Violações dos direitos humanos das mulheres na ditadura, 23(3) Revista Estudos Feministas 1001 (2015).

88 Id. 
the political or judicial realm. However, she rather optimistically points to the fact that truth commissions established in the region have in one way or another addressed sexual violence and made this a matter a public debate. She remarks that,

of the 24 state commissions/committees on truth - a Brazilian phenomenon - of the five... [that] delivered a final report, four incorporated a discussion on gender in some form. ${ }^{89}$

Certain legislative changes regarding sexual violence were introduced. The feminist movement was very important in the struggle for women's rights, including legislative reforms,

These conquests represent one of the principal areas of concern of the feminist movement, "that which is private and that which is public," realigning gender violence as a social problem..$^{90}$

Various women's organizations operated in Brazil in the 1970s to 1980s, uniting their efforts in the struggle for equal rights for equal work, access to contraceptives, abortion rights as well as elimination of sexual violence at home and in the street. ${ }^{91}$ Fernanda Araújo Pereira et Luísa Santos Paulo, however, notes that the impact of women's rights organizations on the overall human rights struggle was rather limited in Brazil (when compared to Argentina) since, while they were united in the streets, they had few chances to alter institutional practices (mainly due to the highly organized nature of the Brazilian military regime). This, in turn, made it much more difficult to challenge "the misogynistic legacy of the regime.".92

Marcelo Torelly believes the Commission's work can in general be regarded as positive: it was able to systematize information (even if it was already known to the public), it named names (unlike previous commissions), it looked into several important high-profile cases (such as the deaths of the former presidents Juscelino Kubitschek and João Goulart) ${ }^{93}$ it classified certain atrocities as crimes against

89 Mariana Joffily, Sexual Violence in the Military Dictatorships of Latin America: Who Wants to Know?, 13(24) Sur - International Journal on Human Rights 165, 176 (2016).

90 Id. at 170 .

91 Memórias da ditadura (Apr. 20, 2019), available at http://memoriasdaditadura.org.br.

92 Fernanda Araújo Pereira \& Luísa Santos Paulo, As violências sexuais e de gênero e a justiça de transição no Brasil e na Argentina: uma análise comparativa dos movimentos de mulheres em cada país, 222 L'Ordinaire des Amériques (2017) (Apr. 20, 2019), available at http://journals.openedition.org/orda/3478.

93 Jan Rocha \& Jonathan Watts, Brazil's Former President Kubitschek Was Murdered, Says Commission, The Guardian, 10 December 2013 (Apr. 20, 2019), available at https://www.theguardian.com/world/2013/ dec/10/brazil-truth-commission-kubitschek-president-murdered. 
humanity and, most importantly, it posed a challenge to the military veto power. ${ }^{94}$ Torelly warns, however, that implementation of the Commission's recommendations (even though many of them are rather general in nature and are not linked to the military rule per se) might be another challenge that the Brazilian society might have to cope with: after Dilma Rousseff's impeachment in 2015, the implementation slowed down, and the creation of a special independent monitoring body was cancelled. In the conditions where serious disillusionment with democracy has been recorded by Latinobarómetro (a non-governmental organization from Santiago, Chile), in Latin American countries, including Brazil, ${ }^{95}$ accompanied by the election of Jair Bolsonaro, a right-wing politician, in January 2019, infamous for his appraisal of the military regime and discriminatory attitude towards race, gender or sexual orientation, ${ }^{96}$ it remains to be seen whether any consistent effort would be made to deal with the traumatic past and address the needs of the survivors.

\section{Conclusion}

Transitional justice, a rapidly developing field, evokes a lot of interest among academics and practitioners. While the field itself is broad and frequently contested as to what measures and mechanisms can be regarded as part of it, truth commissions undoubtedly fall within the scope of transitional justice initiatives. The challenges of truth commissions involve many aspects including dealing with past amnesties, the question of reparations, the link between truth-telling and reconciliation, the capacity of truth commissions to make a contribution to democracy and respect for human rights, the potential preventive effect of public acknowledgement of crimes and its capacity to ensure long-lasting peace. And while earlier research that tackled all these issues contained a lot of wishful thinking, more careful analysis emerged over the past decade that warns against excessive optimism.

One of the areas of transitional justice that remains problematic and is very often context-specific is the gender dimension which includes not only sexual crimes but also a multitude of roles both women and men play in post-conflict and/or postauthoritarian settings.

South African and Brazilian truth commissions, even though they addressed a number of different crimes and were evaluated as rather successful undertakings,

94 Torelly 2018 , at 215.

95 The number of people disillusioned with democracy was recorded to be as high as 71\% (in 2009 the number was 51\%) in Latin American countries. In Brazil, the level of satisfaction with democracy was recorded as the lowest. See Latin Americans Are Dejected About Democracy, The Economist, 8 November 2018 (Apr. 20, 2019), available at https://www.economist.com/the-americas/2018/11/08/ latin-americans-are-dejected-about-democracy.

96 David Child, Who Is Jair Bolsonaro, Brazil's New Far-Right President?, Al Jazeera, 1 January 2019 (Apr. 20, 2019), available at https://www.aljazeera.com/news/2018/10/jair-bolsonaro-brazil-presidentialcandidate-181007020716337.html. 
faced a number of problems in the field of addressing sexual crimes and genderrelated issues more generally. First of all, in the context of patriarchy, when deep societal structures have favored discrimination against women, introducing a gender dimension was not without struggle on the part of various civil society groups that did not want to continue living in the atmosphere of silence and impunity. Secondly, both commissions faced a difficult choice (and in that, they were not different from international criminal tribunals) between protecting the victims who often felt insecure, threatened and marginalized by their community, and at the same time, ensuring the rights of the perpetrators who had to be presumed innocent until proven guilty, and, lastly, trying to achieve the goal they had been established for: the long-term societal interests that would involve peace and reconciliation. As the two cases in our analysis show, the link between transitional justice and rule of law (as well as democratization) is not an obvious one (and whether it is desirable is another difficult question).

Drawing broader conclusions, we would like to remark that while the international community tries to address the challenges, drawing on previous mistakes and lessons learned, there are a number of areas that remain barely touched upon. One of such areas is the criminality of non-state actors. Much of our understanding of transitional justice is based on a classical notion of conflicts (whether international or non-international) that progress from a certain beginning to an end (albeit vaguely defined), with transitional justice measures introduced in the aftermath of the atrocities. However, they may be inadequate to address horrendous acts against girls and women committed by Boko Haram in Nigeria" or the Islamic State across Middle Eastern countries. ${ }^{98}$ And even if international humanitarian law is poorly equipped to deal with non-international armed conflicts, it is hardly suitable to address such issues at all. The increasing involvement of mercenaries and private military companies in combat alters the nature of the conflict and makes existing international law instruments outdated and inadequate.

A serious problem in the context of gender justice in truth commissions remains in assessing the role of transitional justice in shaping and (re)structuring of gender relations in the post-conflict environments, since, frequently, gender imbalance and violence result not from the conflict per se, but from deeper power relations within the society, and from distorted notions of masculinity and femininity. One of the ways to assess gender relations has been the Gender Empowerment Measure (GEM), used by the United Nations Development Programme (UNDP), to plan context-specific policies. The South African Reconciliation Barometer (www.ijr.org.za) set up by the Institute for Justice and Reconciliation (Cape Town) attempted to monitor opinion polls in the country. Obviously, such measurements might be inaccurate, a problem which can

97 Sherrie Russel-Brown, Boko Haram's Violence Against Women and Girls Demands Justice, Council on Foreign Relations, 11 May 2018 (Apr. 20, 2019), available at https://www.cfr.org/blog/boko-haramsviolence-against-women-and-girls-demands-justice.

98 See, for instance, a highly moving memoir by Nadia Murad, The Last Girl: My Story of Captivity, and My Fight Against the Islamic State (2017). 
be addressed by cross-country comparative studies. Up to the present time, as Elin Skaar remarks in her excellent analysis of transitional justice and its contribution to human rights, there have been very few rigorous studies of truth commissions and their impact in general, and their findings have been disparate, at best. ${ }^{99}$

It is certainly impossible to address all of the difficult questions before the commission is set up, and there are no recipes as to how to avoid thorny issues. Certain pragmatic conclusions can be drawn, however: for instance, tailoring the reparations to the needs of the survivors and the communities, combining reparations with other forms of support, provision of certain services (educational, medical, etc.) in a long-term and consistent manner. Transition might only be a short and fleeting moment - therefore, it is vital to incorporate a gender dimension not only in formal, legal mechanisms, but also in other forms of transitional justice, drawing on the research and findings from various disciplines, including criminology, anthropology, psychology, peace and conflict studies, and others.

Representing the work of truth commissions in art, literature, and popular culture as well as memorialization of the traumatic experience also remains an issue of paramount importance. As Aleida Assmann remarks, triumph and trauma remain two categories that necessitate collective re-thinking and re-interpretation of history. Traditional strategies of "dealing with the past" (whether psychotherapeutical, political or cultural) are simply not enough, however, to confront mass atrocities. ${ }^{100}$ Incorporating a gender dimension into these cultural expressions is a vital component of reconciliation.

\section{References}

Andersen E. Transitional Justice and the Rule of Law: Lessons from the Field, 47(1) Case Western Reserve Journal of International Law 305 (2015).

Brounéus K. The Trauma of Truth Telling: Effects of Witnessing in the Rwandan Gacaca Courts on Psychological Health, 54(3) Journal of Conflict Resolution 408 (2010). https://doi.org/10.1177/0022002709360322

Costa Pinto A. Authoritarian Legacies, Transitional Justice and State Crisis in Portugal's Democratization, 13(2) Democratization 173 (2006). https://doi.org/10.1080/ 13510340500523895

Evenson E.M. Truth and Justice in Sierra Leone:Coordination Between Commission and Court, 104(3) Columbia Law Review 730 (2004). https://doi.org/10.2307/4099329

Gibson J.L. Overcoming Apartheid: Can Truth Reconcile a Divided Nation? (New York and Cape Town: Russell Sage Foundation, 2004).

Gil Gil A. The Flaws of the Scilingo Judgment, 3(5) Journal of International Criminal Justice 1082 (2005). https://doi.org/10.1093/jicj/mqi077

\footnotetext{
99 Skaar 2018, at 13.

100 Aleida Assmann, Der lange Schatten der Vergangenheit: Erinnerungskultur und Geschichtspolitik (Munich: C.H. Beck, 2006).
} 
Girelli G. Understanding Transitional Justice: A Struggle for Peace, Reconciliation, and Rebuilding (Cham: Springer, 2017). https://doi.org/10.1007/978-3-319-53606-4

Horne C. Building Trust and Democracy: Transitional Justice in Post-Communist Countries (Oxford: Oxford University Press, 2017). https://doi.org/10.1093/oso/97801 98793328.001.0001

Huyse L. Justice After Transition: On the Choices Successor Elites Make in Dealing with the Past, 20(1) Law \& Social Inquiry 51 (1995). https://doi.org/10.1086/492498

Kiss C. The Misuses of Manipulation: The Failure of Transitional Justice in Post-Communist Hungary, 58(6) Europe-Asia Studies 925 (2006). https://doi.org/10.1080/ 09668130600831142

Lambourne W. \& Rodriguez Carreon V. Engendering Transitional Justice: A Transformative Approach to Building Peace and Attaining Human Rights for Women, 17(1) Human Rights Review 71 (2016). https://doi.org/10.1007/s12142-015-0376-0

Linton S. Women Accused of International Crimes: A Trans-Disciplinary Inquiry and Methodology, 27(2) Criminal Law Forum 159 (2016). https://doi.org/10.1007/s10609016-9280-9

Owens I. et al. Stories of Silence: Women, Truth and Reconciliation, 30 Agenda 66 (1996). https://doi.org/10.2307/4065784

Pendas D.O. Retroactive Law and Proactive Justice: Debating Crimes Against Humanity in Germany, 1945-1950, 43(3) Central European History 428 (2010). https:// doi.org/10.1017/s0008938910000361

Porter E. Gendered Narratives: Stories and Silences in Transitional Justice, 17(1) Human Rights Review 35 (2016). https://doi.org/10.1007/s12142-015-0389-8

Ross F. Bearing Witness: Women and the Truth and Reconciliation Commission in South Africa (London: Pluto Press, 2003). https://doi.org/10.2307/j.ctt18fs5dm

Sarkin J. Carrots and Sticks: The TRC and the South African Amnesty Process (Antwerp: Intersentia, 2005).

Stuit H. Ubuntu Strategies: Constructing Spaces of Belonging in Contemporary South African Culture (London: Palgrave, 2016). https://doi.org/10.1057/978-1-137-58009-2

Tabak S. False Dichotomies of Transitional Justice: Gender, Conflict and Combatants in Columbia, 44 New York University Journal of International Law and Politics 103 (2011). https://doi.org/10.2139/ssrn.1926956

\section{Information about the authors}

Galina Nelaeva (Tyumen, Russia) - Professor, Department of Modern History and World Politics, Institute of Social Sciences and Humanities, Tyumen State University (38 Lenina St., Tyumen, 625000, Russia; e-mail: g.a.nelaeva@utmn.ru).

Natalia Sidorova (Tyumen, Russia) - Associate Professor, Department of Criminal Law and Criminal Procedure, Institute of State and Law, Tyumen State University (38 Lenina St., Tyumen, 625000, Russia; e-mail: n.v.sidorova@utmn.ru). 